\title{
Physicochemical Analysis of open well water Samples near Industrial Area of Niphad, Nashik District, (Maharashtra), India
}

\author{
P.T.Kadave ${ }^{1}$, M.B.Bhor ${ }^{1}$ A.B.Bhor ${ }^{2} \&$ M.S.Bhosale ${ }^{3}$ \\ ${ }^{I}$ (K.K.Wagh Polytechnic, Nashik-422 003. Maharashtra, India.) \\ ${ }^{2}$ (Gokhale Education Society's College of Engineering Nashik-422 005. Maharashtra, India.) \\ ${ }_{3}^{3}$ (Panchavati English Medium School,Igatpuri,Nashik-422403, Maharashtra, India.)
}

\begin{abstract}
The study was carried out to assess the well water quality in and around Niphad (Nashik District.)The quality was assessed in terms of physicochemical parameter. Well water samples were collected from eleven (11) villages in Niphad taluka, during month June 2012 to July 2012. The physicochemical parameters such as pH,Total Dissolved Solids (TDS), Total Solids (TS), Dissolved Oxygen (DO), Biochemical Oxygen Demand (BOD), Total Alkalinity (TA), Total Hardness (TH), Calcium $\left(\mathrm{Ca}^{2+}\right)$, Magnesium $\left(\mathrm{Mg}^{2+}\right)$ Fluorides $\left(\mathrm{F}^{\mathrm{F}}\right)$,Chloride $(\mathrm{Cl})$,Sulphate $\left(\mathrm{SO}_{4}{ }^{2-}\right)$, were analyzed to know the present status of the well water quality. The results were compared with standards prescribed by ISI 10500-91. It was found that the well water was contaminated at few sampling sites. The remaining sampling sites shows physicochemical parameters within the water quality standards and the quality of water is good and it is fit for drinking purpose.
\end{abstract}

Keywords: Drinking water, Physiochemical study, Pollution study, Water quality parameters.

\section{Introduction}

Over $97 \%$ of the total water is available in ocean and other saline bodies, and is not readily usable. Of the remaining 3\%, a little over $2 \%$ is in icecaps and glaciers, Groundwater is the major source of drinking water in both urban and rural areas. Besides, it is an important source of water for the agricultural and industrial sector. Up to last decade it was considered a dependable source of uncontaminated water. Fresh water has become a scarce commodity due to over exploitation and pollution of water. Increasing population and its necessities have lead to the deterioration of surface and sub surface water. Groundwater crisis is not the result of natural factors. It has been caused by human actions. Subsurface water sources are getting polluted due to developmental activities. In south areas of Nasik, particularly in Niphad taluka, there are sugar and wine industries. The effluents from these industries greatly distress the geochemistry of the soil. The discharged chemicals interact with ground water and affect the $\mathrm{pH}$ and other water quality. Hence the south areas of Nashik district were selected to study the effect of sanitary conditions on ground water quality. The social relevance of the problem has encouraged us in carrying out this work.

\section{Study Area}

This study is concentrated on Niphad taluka of the Nashik district, Maharashtra (India) and the area is under heavey irrigation. Fertilizers and pesticides are used in a large amount which gets washed away in nearby river streams or percolate to well water. The whole taluka is covered by deccan trap. The soil of Niphad taluka is filled with disintegrated basalts of various shades from gray to black. This is favorable for the grapes, onions, vegetables, flowers and sugarcane. Sugarcane is one of its most important agricultural products and is the basis for its sugar refining and alcohol distilling industry, The black soil contains high alumina and carbonates of calcium and magnesium with variable amount of potash, low nitrogen and phosphorus. Niphad gets water supply mainly from groundwater that is open wells. These water sources are used for drinking, irrigation and industrial purpose. Location of study area is shown in figure A. 


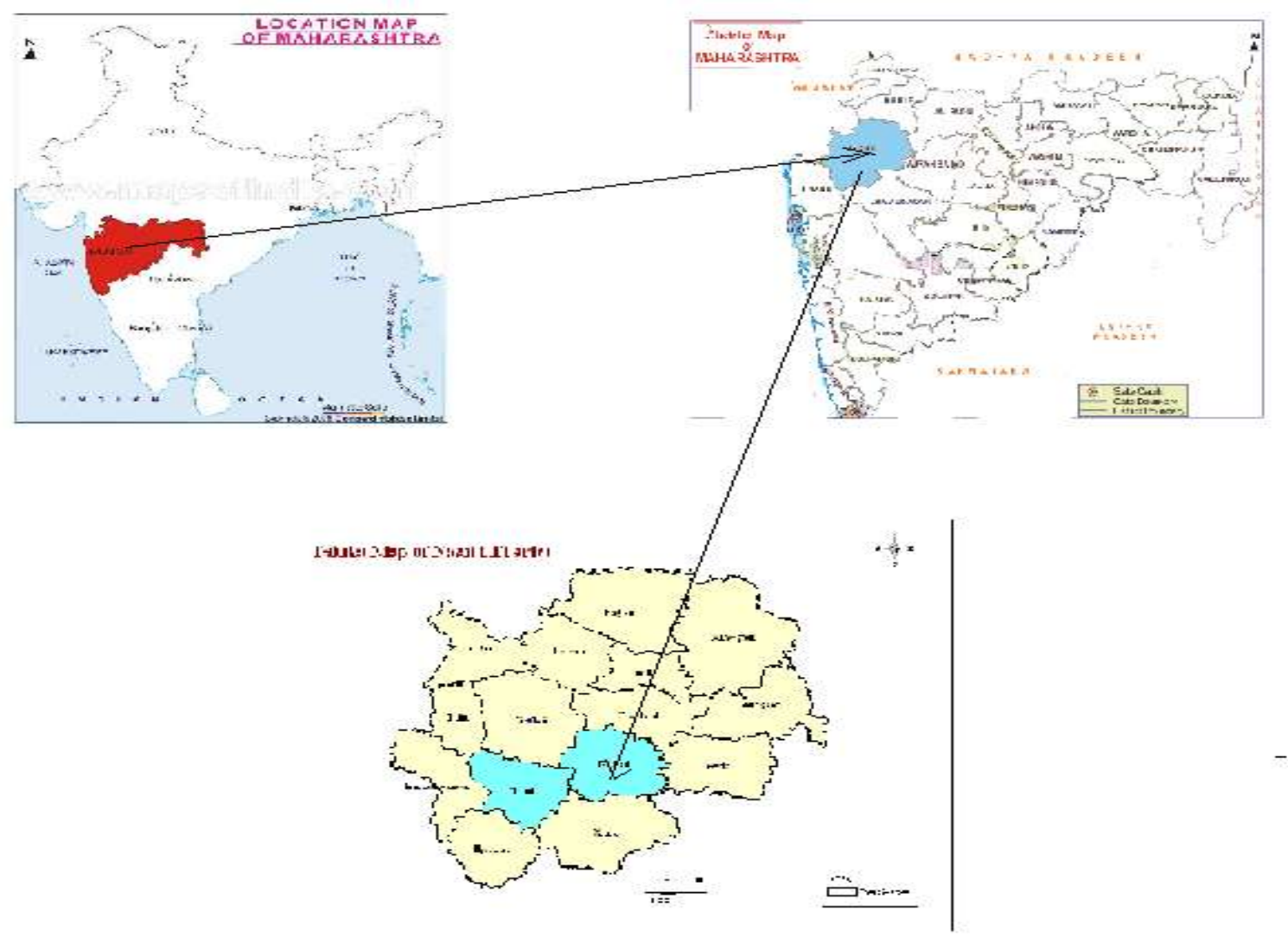

Figure A: Location map of Nashik and Niphad Taluka of Maharashtra, India

\section{Materials And Methods}

All underground water samples are collected from open wells in different parts of the study area during pre-monsoon 2012 season and analyzed for their chemistry. The containers used for sample collection are polythene containers of capacity two liters. These containers were thoroughly cleaned, washed with dilute nitric acid and rinsed before collection. During the present study some of the physical and chemical parameters were determined. The measurement of temperature, $\mathrm{pH}$ and Total Dissolved Solids were taken in the field, immediately after the collection of samples using portable water quality analyzer Chloride, Hardness, Calcium, Magnesium, Total Alkalinity were analyzed by titrimetry, Fluoride,Sulphates were done by the UV Spectrophotometer. Standard procedures used in groundwater analysis are given in Table 1 and Location of sampling stations was given in Table 2 .

\begin{tabular}{|c|c|c|c|}
\hline Sr.No & Parameter & Unit & Method \\
\hline 1. & Temperature & ${ }^{0} \mathrm{C}$ & Thermometer \\
\hline 2. & $\mathrm{pH}$ & ---- & Potentiometric Method \\
\hline 3. & TDS & $\mathrm{mg} / \mathrm{l}$ & Gravimetric Method \\
\hline 4. & TS & $\mathrm{mg} / \mathrm{l}$ & Gravimetric Method \\
\hline 5. & TH & $\mathrm{mg} / \mathrm{l}$ & EDTA Titrimetric Method \\
\hline 6. & $\mathrm{Ca}^{2+}$ & $\mathrm{mg} / \mathrm{l}$ & EDTA Titrimetric Method \\
\hline 7. & $\mathrm{Cl}^{-}$ & $\mathrm{mg} / \mathrm{l}$ & Argentometric Titration Method \\
\hline 8. & $\mathrm{~F}^{-}$ & $\mathrm{mg} / \mathrm{l}$ & Spectrophotometric Method \\
\hline 9. & $\mathrm{SO}_{4}^{2-}$ & $\mathrm{mg} / \mathrm{l}$ & Spectrophotometric Method \\
\hline 10. & D.O & $\mathrm{mg} / \mathrm{l}$ & Titrimetric Method \\
\hline 11. & B.O.D & $\mathrm{mg} / \mathrm{l}$ & Titrimetric Method \\
\hline 12. & $\mathrm{Mg}^{2+}$ & $\mathrm{mg} / \mathrm{l}$ & Titrimetric Method \\
\hline 13. & Total alkalinity & $\mathrm{mg} / \mathrm{l}$ & Titrimetric Method \\
\hline
\end{tabular}




\begin{tabular}{|c|c|c|c|c|c|}
\hline \multirow{2}{*}{ Sr.No } & \multicolumn{5}{|c|}{ Table 2: Location of Sampling Stations } \\
\hline & Location & Land Use & Sr.No & Location & Land Use \\
\hline 1. & Chandori & Agricultural & 7. & Palkhed & Agricultural \\
\hline 2. & Chitegaon & Agricultural & 8. & Pimpalgaon- & Residential \\
\hline 3. & Kasabe-sukene & Agricultural & 9. & Shirwade -Wani & Agricultural \\
\hline 4. & Kokangaon & Agricultural & 10. & Sayyad -Pimpri & Agricultural \\
\hline 5. & Niphad & Industrial & 11. & Sawargaon & Residential \\
\hline \multirow[t]{3}{*}{6.} & Saikheda & Residential & & & \\
\hline & \multicolumn{5}{|c|}{ Total sampling sites. $=11$} \\
\hline & \multicolumn{5}{|c|}{ Table 3: Indian Standard Specifications for drinking water IS 10500} \\
\hline Sr .No & Parameter & $\begin{array}{l}\text { Required Desirable } \\
\text { Limit }\end{array}$ & Remar & & \\
\hline 1 & Temperature & -------- & ------- & & \\
\hline 2 & $\mathrm{pH}$ & 6.5 to 8.5 & May be & relaxed up to $9.2 \mathrm{il}$ & absence \\
\hline 3 & TDS & 500 & May be & extended up to 200 & \\
\hline 4 & $\mathrm{TS}$ & & & & \\
\hline 5 & TH & 300 & May be & extended up to 600 & \\
\hline 6 & $\mathrm{Ca}^{2+}$ & 75 & May be & extended up to 200 & \\
\hline 7. & $\mathrm{Cl}^{-}$ & 250 & May be & extended up to 10 & \\
\hline 8 & $\mathrm{~F}^{-}$ & 0.6 to 1.2 & $\begin{array}{l}\text { If the li } \\
\text { Max. li }\end{array}$ & $\begin{array}{l}\text { nit is below } 0.6 \text { wa } \\
\text { nit is extended to } 1\end{array}$ & hould be rejected, \\
\hline 9 & $\mathrm{SO}_{4}^{2-}$ & 150 & May be & extended up to 400 & \\
\hline 10 & D.O & --------------- & -------- & -.- - - & \\
\hline 11 & B.O.D & ----------------- & --------- & ..-- & \\
\hline 12 & $\mathrm{Mg}^{2+}$ & 30 & May be & extended up to 100 & \\
\hline 13 & Total alkalinity & 200 & May be & extended up to 600 & \\
\hline
\end{tabular}

Water samples from the selected sites were collected during June 2012-July 2012 and taken in precleaned polyethylene bottles. The samples after collection were immediately placed in dark boxes and processed within $6 \mathrm{~h}$ of collection.

\section{Physicochemical analysis}

The collected samples were analyzed for major physical and chemical water quality parameters like $\mathrm{pH}$, Total Dissolved solids (TDS), Total Hardness (TH), $\mathrm{Ca}^{2+}, \mathrm{Mg}^{2+}$ as per the method Assessment of Ground Water Quality described in "Standard methods for the examination of water and wastewater American Public Health Association (APHA).The parameters present in the water sample can be calculated by using various methods3-4. The $\mathrm{pH}$ of all the water samples was determined using a $\mathrm{pH}$ meter. The chloride, total hardness and total alkalinity were estimated by the standard methods of water and waste waters.

\section{Results and Discussion}

The physicochemical data of the wells water sample collected in June 2012 and July- 2012 are recorded in table 3 respectively. The results of the samples vary with different collecting places because of the different nature of the soil contamination.

Table 4: Water quality parameters of samples

\begin{tabular}{|c|c|c|c|c|c|c|c|c|c|c|c|c|c|c|}
\hline $\begin{array}{l}\mathbf{S} \\
\mathbf{r}\end{array}$ & $\begin{array}{l}\text { Parameter } \\
\mathrm{s}\end{array}$ & $\begin{array}{l}\text { T } \\
\text { e } \\
\text { m }\end{array}$ & pH & $\begin{array}{l}\text { TD } \\
\text { S }\end{array}$ & TS & TH & $\mathrm{Ca}^{2+}$ & $\mathrm{Cl}^{-}$ & F- & $\mathrm{SO}_{4}{ }^{2}$ & $\begin{array}{l}\text { D. } \\
\text { O }\end{array}$ & $\begin{array}{l}\text { B. } \\
\text { O. } \\
\text { D }\end{array}$ & $\begin{array}{l}\mathbf{M} \\
\mathbf{M g}^{2+}\end{array}$ & TA \\
\hline & & $\begin{array}{l}\mathrm{O}^{\circ} \\
\mathrm{C}\end{array}$ & -- & $\begin{array}{l}\mathrm{mg} / \\
\text { lit. }\end{array}$ & $\begin{array}{l}\mathrm{mg} / \\
\text { lit. }\end{array}$ & $\mathrm{mg} / \mathrm{lit}$ & $\begin{array}{l}\mathrm{mg} / \\
\text { lit. }\end{array}$ & $\begin{array}{l}\mathrm{mg} / \mathrm{li} \\
\mathrm{t} .\end{array}$ & $\begin{array}{l}\mathrm{mg} \\
/\end{array}$ & $\begin{array}{l}\mathrm{mg} / \\
\text { lit. }\end{array}$ & $\begin{array}{l}\mathrm{mg} \\
\text { /lit. }\end{array}$ & $\begin{array}{l}\mathrm{mg} \\
/\end{array}$ & $\begin{array}{l}\mathrm{mg} / \mathrm{li} \\
\mathrm{t} .\end{array}$ & $\begin{array}{l}\mathrm{mg} / \\
\text { lit. }\end{array}$ \\
\hline 1 & Chandori & $\begin{array}{l}2 \\
6\end{array}$ & 6.4 & $\begin{array}{l}102 \\
9\end{array}$ & $\begin{array}{l}103 \\
2\end{array}$ & 733.0 & 64.2 & $\begin{array}{l}358 . \\
2\end{array}$ & 0.7 & 42.0 & 6.0 & 2.4 & 84.4 & $\begin{array}{l}260 . \\
4\end{array}$ \\
\hline
\end{tabular}


Physicochemical Analysis of open well water Samples near Industrial Area of Niphad, Nashik

\begin{tabular}{|c|c|c|c|c|c|c|c|c|c|c|c|c|c|c|}
\hline 2 & Chitegaon & $\begin{array}{l}2 \\
6\end{array}$ & 6.6 & 320 & 328 & 209.4 & 52.5 & $\begin{array}{l}358 . \\
2\end{array}$ & 0.7 & 28.0 & 4.7 & 2.4 & 97.7 & $\begin{array}{l}133 . \\
6\end{array}$ \\
\hline 3 & Kasabe- & 2 & 6.3 & 979 & 992 & 994.8 & 8 & & 0.7 & 96.0 & 3.9 & 3.2 & $\begin{array}{l}128 . \\
9\end{array}$ & 279 \\
\hline 4 & Kokangaon & $\begin{array}{l}2 \\
5\end{array}$ & 6.3 & $\begin{array}{l}113 \\
0\end{array}$ & $\begin{array}{l}113 \\
2\end{array}$ & 5 & 181. & 97.7 & 0.6 & $\begin{array}{l}121 . \\
0\end{array}$ & 5.6 & 2.3 & $\begin{array}{l}164 . \\
5\end{array}$ & $\begin{array}{l}243 . \\
5\end{array}$ \\
\hline 5 & Niphad & $\begin{array}{l}2 \\
6\end{array}$ & 6.8 & 612 & 625 & 759.2 & 63.3 & & 0.6 & 16.0 & 3.5 & 2.8 & 62.2 & 225 \\
\hline 6 & Saikl & 5 & 6.7 & 320 & 328 & 602.1 & 56.1 & 97.7 & 0.6 & 10.0 & 5.9 & 3.1 & 22.2 & $\begin{array}{l}172 . \\
5\end{array}$ \\
\hline 7 & Palkhed & $\begin{array}{l}2 \\
6\end{array}$ & 6.5 & 600 & 605 & 863.9 & 14 & 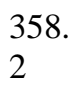 & 0.7 & 38.0 & 3.7 & 1.8 & $\begin{array}{l}134 . \\
5\end{array}$ & $\begin{array}{l}170 . \\
8\end{array}$ \\
\hline 8 & Pimpalgao & $\begin{array}{l}2 \\
6\end{array}$ & 6.6 & 218 & 223 & 602.1 & 48.9 & $\begin{array}{l}293 . \\
1\end{array}$ & 0.7 & $\begin{array}{l}107 . \\
0\end{array}$ & 4.3 & 3.5 & 26.7 & $\begin{array}{l}138 . \\
8\end{array}$ \\
\hline 9 & - & $\begin{array}{l}2 \\
5\end{array}$ & 6.6 & 461 & 462 & 628.3 & 35.0 & $\begin{array}{l}293 . \\
1\end{array}$ & 0.6 & 76.0 & 3.1 & 1.4 & 93.0 & $\begin{array}{l}199 . \\
7\end{array}$ \\
\hline $\begin{array}{l}1 \\
0\end{array}$ & Sayyad- & $\begin{array}{l}2 \\
5\end{array}$ & 6.8 & 294 & 296 & 392.7 & 56.1 & $\begin{array}{l}423 . \\
4\end{array}$ & 0.6 & 20.0 & 5.5 & 2.8 & 48.9 & $\begin{array}{l}182 . \\
8\end{array}$ \\
\hline 1 & Sawargaon & $\begin{array}{l}2 \\
6\end{array}$ & 6.8 & 488 & 498 & 471.2 & 79.6 & $\begin{array}{l}423 . \\
4\end{array}$ & 0.7 & 51.0 & 5.5 & 3.2 & 62.2 & $\begin{array}{l}160 . \\
8\end{array}$ \\
\hline
\end{tabular}

VI. Conclusion:

The analysis of the open well water quality parameters from eleven different villages from Niphad taluka shows that the pH, TDS, Chloride, Total Hardness, Calcium Magnesium and BOD values are not well within the permissible limits. Average of alkalinity has exceeded the desirable limits which are due use of large amount of pesticides, fertilizers in land and percolation of industrial waste water affects the water quality .From the results of the present study it may be said that the groundwater of eleven villages from Niphad taluka is not fit for domestic and drinking purposes, need treatments to minimize the Contamination especially the alkalinity. There is need of an increasing awareness among the people to maintain the groundwater at their highest quality and purity levels and the present study may prove to be useful in achieving the same.

\section{Acknowledgement}

Authors are thankful K.K.W.I.E.E R Nashik and K.K.W P.Nashik permission to carry out the present investigation and providing necessary laboratory facilities. Authors also thankful to Mr.A.L.Varne,Mr. M.N.Shete,Mr.P.S.Bhandari,Mr.B.L.Bhor,Mr.Y.P.Mahajan,Mr.K.T.Shinde,Mr.G.B.Dabhade for inspiration and valuable suggestions during research work.

\section{References}

[1] S. Gupta, A. Kumar, C. K. Ojha and G. Singh, J Environmental Science and Engineering, 46(1), 74-78 (2004).

[2] P. A. Hmilton and D. K. Helsel, Ground Water, 33, 2, (1995)

[3] E. Brown, M. W. Skovgstd and M. J. Fishman, Methods for Collection and Analysis of Water Samples for Dissolved Minerals and Gases, Vol. 5 (1974).

[4] A. I. Vogel, Text Book of Inorganic Quantitative Analysis, 4 th Ed., ELBS, London (1978).

[5] Guidelines for drinking water quality, World Health organization, Geneva, Vol.1, (1993).

[6] Guidelines for drinking water quality, World Health organization, Geneva, Vol.2, (1999).

[7] Fluoride in drinking water, WHO / IWA, (2001).

[8] Water Facts- Water and rivers commission, Government of Western Australia, Dec. (1998).

[9] M. D. Kumar and S. Tushar, The Hindu survey of the Environment, 7-9, 11-12 (2004).

[10] N. S. Rao, Hydrological Sci. J/J des Sci. Hydrologiques, 48(5), 835-847 (2003).

[11] P. C. Mishra and R. K. Patel, Indian J. Environ. Ecoplan, 5(2), 293-298 (2001).

[12] S. Naik and K. M. Purohit, Indian J. Environ. Ecoplan, 5(2), 397-402 (2001).

[13] B. K. Purandra, N. Varadarajan and K. Jayshree, Poll Res., 22(2), 189 (2003).

[14] APHA(American Public Health Association) standard methods for examination of water and waste water, NW, DC 20036 (1994).

[15] A. K. Rana, M. J. Kharodawala, J. M. Patel, R. K. Rai, B. S. Patel and H. R. Dabhi, Asian Journal of Chemistry, 14, 1209, (2002). 